\title{
Aquaponic Biofloc Technology by Swamp Bacteria Probiotic for Clarias Catfish Rearing
}

\author{
Marini Wijayanti ${ }^{1 *}$, Mohamad Amin ${ }^{1}$, Tanbiyaskur ${ }^{1}$, Dade Jubaedah ${ }^{1}$, Kukuh Jaya ${ }^{1}$, M \\ Aiman Ziyad ${ }^{1}$ and Marsi $^{2}$ \\ ${ }^{1}$ Department of Fisheries, Faculty of Agriculture, Sriwijaya -University. Jl. Palembang Prabumulih \\ Km 32, Indralaya, Ogan Ilir, South Sumatera 30862 Indonesia \\ ${ }^{2}$ Department Of Soil Science, Faculty of Agriculture, Sriwijaya -University. Jl. Palembang \\ Prabumulih Km 32, Indralaya, Ogan Ilir, South Sumatera 30862 Indonesia
}

*Correspondence :
mariniwijayanti@fp.unsri.ac.id

Received : 2020-12-01

Accepted : 2021-06-26

Keywords :

Aquaponics, Biofloc, Clarias catfish production

\begin{abstract}
Conventional catfish culture in Ogan Ilir (OI) have not optimal production, it can be increased by biofloc and aquaponics with local swamp bacteria as a starter. The purpose of this study was to apply biofloc technology and a combination of aquaponic-biofloc to increase the productivity of catfish (Clarias sp.) rearing. The study used two ponds, a biofloc circular pond and a combined biofloc and aquaponic (biofloqua) for two months. The results of the specific growth rate of fish in the aquaponic biofloc system were higher than that of the biofloc system alone. The survival of the fish during two rearing months of the Biofloqua system was $100 \%$ while the Biofloc system was $92-96 \%$. The water quality data that measured were temperature, $30.3-31.9^{\circ} \mathrm{C}$, Dissolved oxygen 4.5-7.2 mg. $.^{-1}, \mathrm{pH} 6-7$, and ammonia concentration 0.27-0.71 mg..$^{-1}$ in the biofloc system and $29.5-31.3^{\circ} \mathrm{C}, 4.7-7.4 \mathrm{mg} .1^{-1}, \mathrm{pH}$ 6-7, 0.20-0.53 mg..$^{-1}$ in biofloqua system, respectively. The floc volume formation rate in the biofloc system alone reached 1.1 ml..$^{-1}$ per day, which was above the floc formation rate for the biofloqua system $0.42 \mathrm{ml}^{-1} \mathrm{l}^{-1}$ per day, due to the use of nutrients for plant growth. The combination of biofloc and aquaponics showed more optimal growth performance and both were efficient in feed (Food Conversion Ratio / FCR <1.00). Although the results of the $5 \%$ level $t$ test showed no difference in the performance of the aquaculture biota between the two systems, Biofloqua can be an alternative to increase fish farmer income by harvesting vegetables and fish together.
\end{abstract}

\section{INTRODUCTION}

The conventional culture of catfish (Clarias sp.) in Sakatiga village has a relatively low fish survival problem. Sakatiga village fish farmers currently need an aquaculture system to support the growth and production of more productive fish culture, especially catfish in swamp areas. DJPB (2018) stated that conventional cultivation has a stocking density of 100 fishes/ m3. To get optimal fish production, biofloc technology is needed to increase the production of catfish with a stocking density of 500 fish $/ \mathrm{m}^{3}$ (Rusliadi et al., 2018). This method could produce 20\% higher fish biomass with a fast harvest period of abou 
20\% (2.5 months) of conventional methods (Faridah et al., 2019), and FCR less than 1.00 (BBPBAT, 2005).

In principle, biofloc technology utilizes microbes in the form of selected heterotrophic bacteria for water quality management based on the ability of bacteria to decompose organic and inorganic Nitrogen (Ekasari, 2009). The heterotrophic bacteria that make up the biofloc include Bacillus sp., Bacillus licheniformis, Bacillus megaterium, Bacillus polmyxa, and Lactobacillus sp. (Simanjuntak, 2017). The floc formation is not only composed of floc-forming heterotrophic bacteria and filamentous bacteria but also from zooplankton, microalgae, fungi, suspended particles, and detritus (De Schryver et al., 2008). Biota and organic materials that accumulate around bound cells form floc which can be a food source for shrimp and fish (Crab et al., 2007).

The cultivation with high stocking density causes a decrease in water quality due to the accumulation of organic matter. The decreasing water quality is indicated by the water becoming smelly, so the ammonia concentration increases and the fish appetite decreases. To improve water quality, it can be done by applying an aquaponics system. Aquaponics can help reduce nitrate concentrations through the direct utilization of nitrates by plants (Pratama et al., 2017). Aquaponics, in principle, is optimizing narrow land to get maximum results such as fish and vegetables. The combination of biofloc and aquaponics will help maintain water quality in catfish cultivation. It can optimize stocking density cultivation as well as research on the optimization of stocking density for catfish cultivation with biofloc and Nitrobacter systems, support the highest specific growth rate and the lowest FCR of fishes (Puspita and Sari, 2018). The laboratory-scale snakehead fish with swamp probiotic starter could give the best performance of fish and water quality in biofloc technology of rearing system (Wijayanti et al., 2020).
An IMTA (Integrated Multitrophic Aquaculture) system can be formed by integrating Biofloc Technology and Aquaponic System (BIOFLOQUA = Biofloc Aquaponic System) or called Bioflokua. According to Goada et al. (2015), the IMTA system achieves the best average net income and can cover production costs by achieving an economic surplus capacity of 47-53\% and a recovery period for invested capital of fewer than 2.17 years, so that it can become an opportunity for small-scale business units in the country -developing country. Aquaponics and biofloc systems have advantages when compared to conventional fish production. This system uses only a single tank to produce vegetables and fish together. Farmers can produce catfish using an aquaponic system with or without biofloc, which can increase their productivity (da Rocha et al., 2017).

The pilot in the form of a demonstration plot for the aquaponic biofloc cultivation system is expected to prove that simple aquaponic biofloc technology innovation can provide benefits that can ensure sustainable business because it is profitable and environmentally friendly (da Rocha et al., 2017; Pinho et al., 2017). The aim of this study is the application of Biofloc and Biofloqua technology (integrated Biofloc and Aquaponics) with swamp probiotic starter for increasing the productivity of catfish (Clarias sp.) rearing culture in farmer groups business at Ogan Ilir swamp area.

\section{METHODOLOGY}

\section{Place and Time}

This activity was carried out from November 2019 to March 2020 in the agribusiness fisheries farmer group in the village of Sakatiga Ogan Ilir.

\section{Research Materials}

This study used catfish fingerlings (weight $7 \pm 2 \mathrm{~g}$ and length $9.5 \pm 1.7 \mathrm{~cm}$ ), feed $(30 \%$ proteins), probiotics from swamps, kangkong seeds, rock wool, 
water, salt, dolomite lime, and molasses. The tools used were circular pools (diameters $2 \mathrm{~m}$ ), pipes, hoses, net pots, water pumps, blowers, rulers, scales, im hoff-cones ( $1 \mathrm{~L}), \mathrm{pH}$ meters, DO meters, and thermometers.

\section{Research Design}

The research data collection method was carried out experimentally with two round ponds arranged for the biofloc system and the aquaponic biofloc system as two fish populations in different systems with completely randomized design (two treatments and two repetitions). Data of 30 fishes per pond on length and weight growth were taken as replications. Measurement of water quality was carried out twice in each pond.

\section{Work Procedure \\ Pond Preparation}

The pond used was a circular tarpaulin pond with a diameter of $2 \mathrm{~m}$, a height of $1 \mathrm{~m}$, and a water level of $0.8 \mathrm{~m}$. Preparation of the pond was carried out to sanitize by brushing to remove dirt from the wall, and drying for 60 minutes with sunlight to kill pathogenic bacteria.

\section{Pond Water Preparation}

Preparation of rearing pond water began with the spread of salt and lime. The dosages of the ingredients used are presented in Table 1.

Table 1. Material for water pond preparation.

\begin{tabular}{lll}
\hline Materials & Quantity $/ \mathrm{m}^{3}$ & Total quantity/pond $\left(2.5 \mathrm{~m}^{3}\right)$ \\
\hline Salt & $1 \mathrm{~kg}$ & $2.5 \mathrm{~kg}$ \\
Lime & $50 \mathrm{~g}$ & $125 \mathrm{~g}$ \\
\hline
\end{tabular}

Quantities of salt and molassesbased on Sucipto et al. (2018) were 1 $\mathrm{kg} / \mathrm{m} 3$ of water and lime were $50 \mathrm{~g} / \mathrm{m} 3$ of water. So, the salt that was spread into the pond as much as $2.5 \mathrm{~kg}$ and $125 \mathrm{~g}$ of lime were first dissolved with water until it was homogeneous then spread into the water, then it was incubated for 1 day. The addition of salt to the media aimed to kill microorganisms such as bacteria and fungi due to the nature of the salt which hydrolyzes the microbial cells so that the microbial cells die (Rimbiyastuti et al., 2016).

\section{Biofloc Medium Preparation}

Molasses is a carbon source that is spread into the media as a nutrient for heterotrophic bacteria which breaks down suspended organic matter in the media (Crab et al., 2012). Molasses must be cooked before use for separating with its dregs and killing contaminant bacteria. The addition of molasses-based on Sucipto et al. (2018) was as much as $100 \mathrm{ml}$ per $\mathrm{m}^{3}$ with a media volume of $2.5 \mathrm{~m}^{3}$ so the volume of molasses added was $250 \mathrm{ml}$.
Molasses were dissolved with water and then evenly distributed at the existing aeration point. Furthermore, the addition of molasses was carried out every 7 days with quantity calculated by the formula based on Sucipto et al. (2018).

Molasse $\mathrm{ml} / \mathrm{L}=\frac{\mathrm{F}}{150 \mathrm{~g}} \times 100 \mathrm{ml}$

Where:

$\mathrm{F}=$ Daily feed $(\mathrm{g})$

The probiotic used was Bacillus sp. and Streptomyces sp. swamp origin, at a dose of $10^{5} \mathrm{CFU} / \mathrm{mL}^{-1}$ (Wijayanti et al., 2020). The media must be incubated for 7 days, then healthy catfish (Clarias sp.) can be spread in the pond.

\section{Catfish Stocking}

The stocking of fish in the aquaculture container was started by measuring the sample of catfish, measured the length and weight at the beginning of stocking. The fishes used were $7 \pm 0.5 \mathrm{~cm}$ in size with a stocking density of 500 fishes per $\mathrm{m}^{3}$ (Ma'ruf, 2012). The two treatments were biofloc ponds without aquaponics and combined ponds with aquaponics, 
both of which were stocked with 1250 catfish. The stocking of catfish carried out in the morning when the water conditions are normal with prior acclimatization for reducing the stress of fish.

\section{Water Spinach Planting Preparation}

Water spinach sowed with seeds at Rockwool for 8 days in room temperature conditions without sunlight. It spread into aquaponic containers after some roots and leaves appear. They put on aquaponic media when the fish have been stocked for a week in the pond.

\section{Fish Rearing and Feeding}

Rearing fish was carried out for 2 months. The weight and length of the fish were sampled each week. Feed provided with $30 \%$ protein. Feeding with the feeding rate (FR) method was given as much as $1 \%$ of the biomass for 4 days, and then feeding at satiation. Feeding was done 3 times a day, at $08.00,12.00$ and 16.00 .

\section{Parameters}

Absolute length growth was measured by taking fish samples and measuring the initial length of the fish when stocked and the length of the fish at the end of rearing. Total length growth can be calculated using the formula (Effendie, 2002):

$\mathrm{La}=\mathrm{Lt}-\mathrm{Lo}$

Where:

La $=$ Total length growth $(\mathrm{cm})$

Lt $=$ Final length $(\mathrm{cm})$

Lo = Initial length $(\mathrm{cm})$

Total weight growth was measured by taking fish samples and measuring the initial weight of the fish when stocked and the weight of the fish at the end of maintenance, calculated using the formula (Effendie ,2002) :

$\mathrm{Wm}=\mathrm{Wt}-\mathrm{Wo}$

Where

$\mathrm{Wm}=$ Total weight growth $(\mathrm{g})$

$\mathrm{Wt}=$ final weight $(\mathrm{g})$

Wo = initial weight $(\mathrm{g})$

The feed conversion ratio shows the efficiency of the feed used to increase each gram of fish weight as the effect of feeding.
The calculation of the feed conversion formula based on Hanley (1991) :

$\mathrm{FCR}=\frac{\mathrm{F}}{\mathrm{Wt}+\mathrm{D}-\mathrm{Wo}} \times 100 \%$

Where:

$\mathrm{FCR}=$ Feed convertion ratio $(\%)$

$\mathrm{F}=$ dry weight of feed given $(\mathrm{g})$

$\mathrm{Wt}=$ the wet weight of the fish at the end of rearing $(\mathrm{g})$

$W_{0}=$ the wet weight of the fish at initial rearing $(\mathrm{g})$

$\mathrm{D}$ = the wet weight of dead fish during rearing(g)

The survival rate shows the percentage value of the fish's ability to survive at the end of rearing, calculated following the formula (Effendie, 2002) :

$\mathrm{SR}=\frac{\mathrm{Nt}}{\mathrm{No}} \times 100 \%$

Where:

$\mathrm{SR}=$ Survival rate of fish rearing (\%)

$\mathrm{Nt}=$ The final quantity of fish at the end of rearing $(\mathrm{g})$

No $=$ The initial quantity of fish at initial rearing (g)

Floc volume measurements were carried out every morning at the beginning and end of the catfish rearing activities. Measurements were made by inserting a $1000 \mathrm{ml}$ water sample into the Imhoff cone and leaving it for 15 minutes then the floc settled on the bottom and the results were immediately seen on the scale in the Imhoff cone. It was then calculated with the formula (Suryaningrum, 2014):

Floc Volume

$=\frac{\text { Volume of floc at the bottom of ilmhoff cone }(\mathrm{ml})}{\text { Volume of water sample }(\mathrm{l})}$

measured were $\mathrm{pH}$ (with $\mathrm{pH}$ meter), dissolved oxygen (with DO meter), and temperature (with thermometer) on the culture medium. Measurements were carried out every 3 times a week during the rearing time. Ammonia measurements were carried out at the beginning and end of the rearing using the spectrophotometric method.

\section{Data Analysis}

Data analysis was performed using the T-test at a 5\% level for growth and survival rate of fish, and regression methods on the growth of fish, floc volume in both systems, the biofloc and the 
aquaponic-biofloc ('biofloqua') systems. Data analysis was carried out descriptively on water quality by collecting primary data and secondary data. Primary data is data obtained from direct data collection or based on activities and secondary data obtained from journals and books as supporting literature (Andrews et al., 2012).

\section{RESULTS AND DISCUSSION}

Data on the results of growth in length and absolute weight and the ratio of catfish feed conversion in maintenance are presented in Figures 1, 2, 3, and 4. The data in Table 3 shows the results obtained by the biofloc pond, the average of total weight gain and total length $8.00 \mathrm{~g}$ and $6.62 \mathrm{~cm}$ in the first month, and $21.79 \mathrm{~g}$ and $2.38 \mathrm{~cm}$ in the second month, respectively. The aquaponic biofloc (Biofloqua) ponds showed a slightly better performance than biofloc pond, with an average weight and length growth value of $8.17 \mathrm{~g} ; 6.67 \mathrm{~cm}$ in the first month and $22.30 \mathrm{~g} ; 2.43 \mathrm{~cm}$ in the second month. The results of T-test $5 \%$ level showed that the Biofloc system and the Biofloqua system had no effect on fish growth, both in weight and length.

Table 2. The weight and length of Catfish and Water Spinach in Biofloc and Biofloqua pond systems.

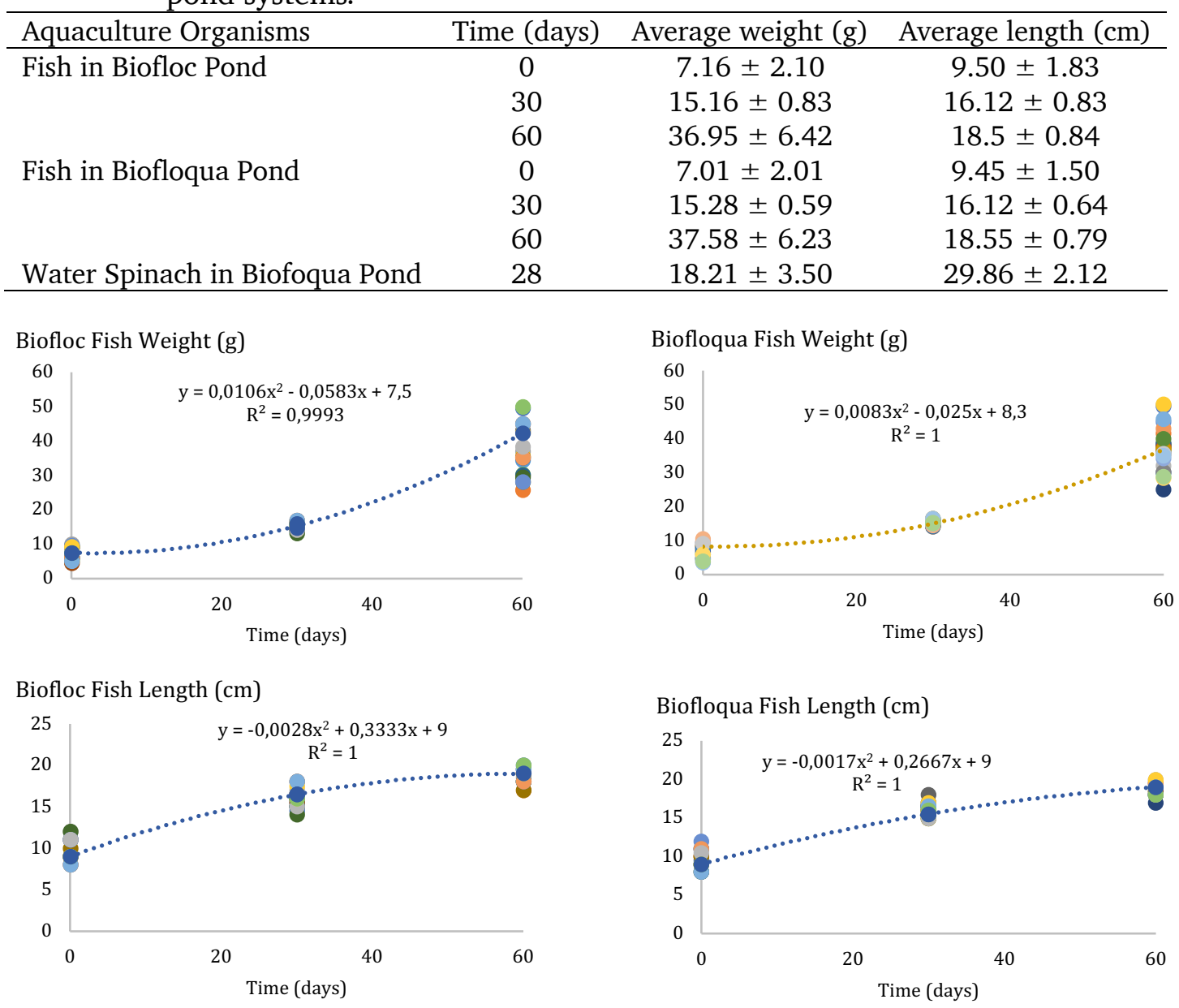

Figure 1. Weight and length growth of Catfish in Biofloc and Biofloqua systems.

Fish growth is influenced by nutritional adequacy and fish appetite. A high fish appetite can boost the growth rate of fish and is supported by nutrients, especially protein in feed. According to
Alfia et al. (2013), a decrease in water quality can affect the appetite of fish resulting in reduced nutrient intake to the body, stunted growth. If it goes on for a long time it will result in the death of fish. 
The growth of catfish with a combined biofloc and aquaponic culture system has the advantage of improving water quality by reducing organic matter, which is more effective by the work of bacteria and recirculation through plants which causes a slightly higher appetite compared to biofloc ponds without aquaponics with feed consumption data for rearing time $9500 \mathrm{~g}$ biofloc pond and combination of biofloc and aquaponics was $10100 \mathrm{~g}$ higher in the first month. Shah et al. (2018) showed that the amount of feed given and the quality of feed has an effect on fish growth. The role of probiotics in contributing proteins and enzymes that

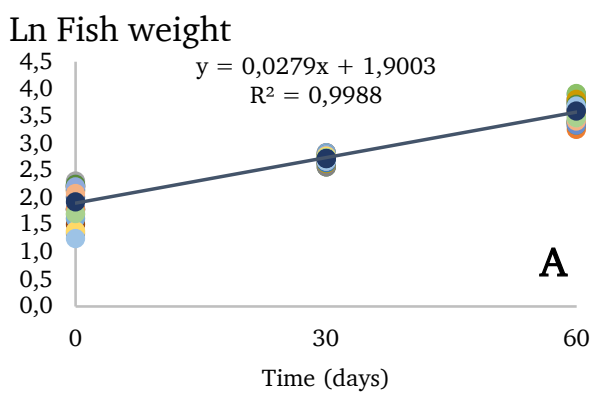

are useful for helping fish digestion can increase the growth rate (Widanarni, 2012).

The specific growth rates of fish weight and length in the Aquaponic Biofloc and Biofloc systems are shown in the regression in Figures 2 and 3. Linear regression of fish weight growth in aquaponic biofloc and biofloc systems shows the equation $\mathrm{y}=0.0279 \mathrm{x}+1,9003$ $\left(\mathrm{R}^{2}=0,9988\right)$ and $\mathrm{y}=0.0285 \mathrm{x}+1.8864$ $\left(\mathrm{R}^{2}=0.9993\right)$, which means that the specific growth rate of fish weight in the biofloc system is $2.79 \%$ per day while in the aquaponic biofloc system it is $2.85 \%$ per day.

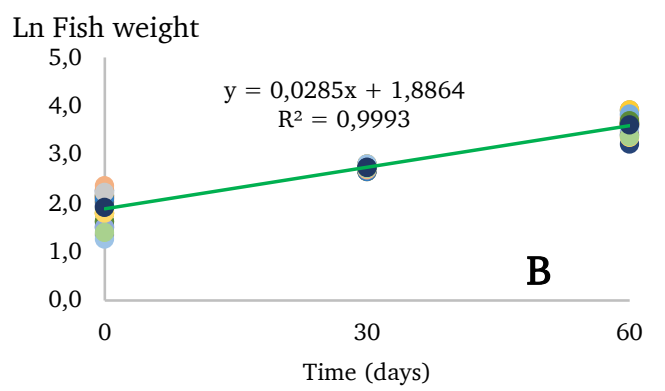

Figure 2. Regression of Ln average weight of fish in Biofloc (A) and Biofloqua (B) ponds on rearing time (days).
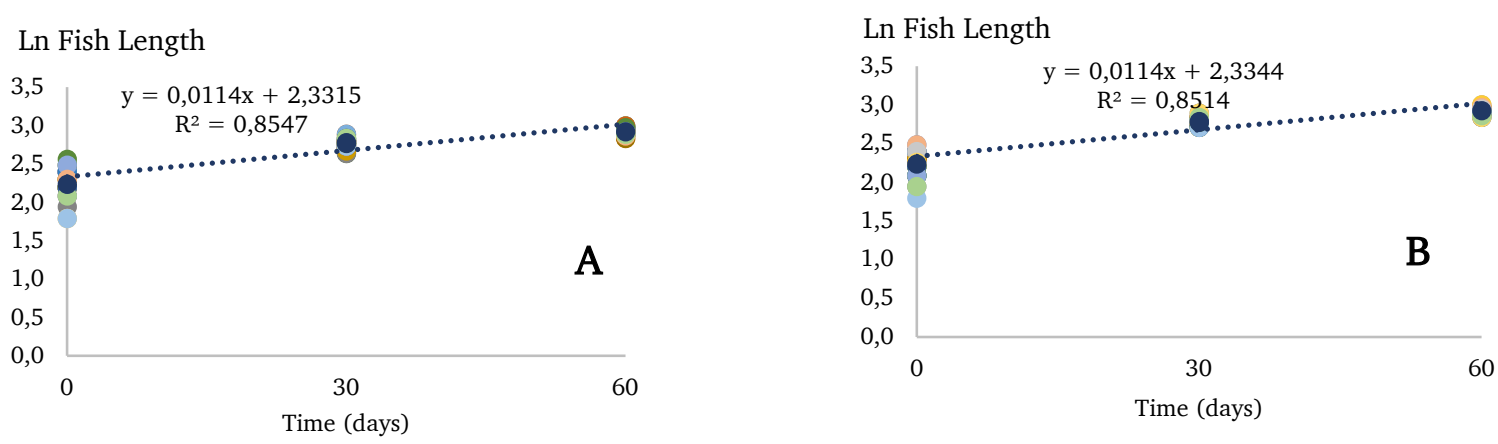

Figure 3. Regression of Ln average length of fish in Biofloc (A) and Biofloqua (B) ponds on rearing time (days).

The specific growth rate of fish in the aquaponic biofloc system is higher than that of the biofloc system alone. Linear regression of fish length growth in biofloc and aquaponic biofloc systems shows the equation $\mathrm{y}=0.0114 \mathrm{x}+2.3315$ $\left(\mathrm{R}^{2}=0.8547\right)$ and $\mathrm{y}=0.0114 \mathrm{x}+2.3344$ $\left(\mathrm{R}^{2}=0.8514\right)$, which means The specific growth rate of fish weight in the biofloc and aquaponic biofloc systems was the same, namely $1.14 \%$ per day. The integration of biofloc and aquaponics systems can increase the growth rate of fish weight but does not increase the length growth rate.

Feed conversion ratio (FCR) is the ratio between the weight of feed that has been given and the biomass of fish obtained with the same unit weight. The value of the feed conversion ratio is influenced by the quality of the feed given 
and the ability of the fish to absorb feed nutrients into biomass (Handajani, 2011).

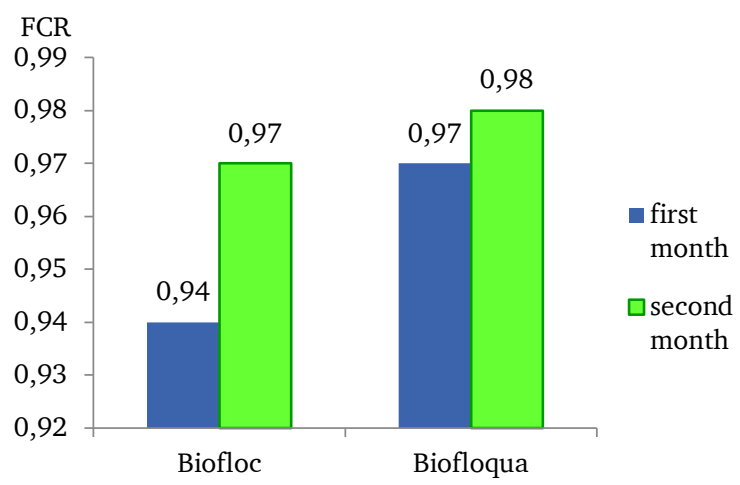

Figure 4. Feed Convertion Ratio (FCR) of Catfish culture on two months rearing time.

The smaller value of the feed conversion ratio shows the higher effectiveness and efficiency of the feed given (Shah et al., 2018). The feed conversion ratio value in the biofloc pond got the best results because the value was less than 1, 0.94 (first month); 0.97 (second month), and the combined biofloc and aquaponics, 0.97 (first month); 0.98 (second month). According to DJPB (2018), they stated that catfish farming with the biofloc system can reduce the feed conversion ratio value of less than 1 , which means feed efficiency because to produce $1 \mathrm{~kg}$ of biomass, less than $1 \mathrm{~kg}$ of feed is needed.

The feed efficiency obtained by both treatments is caused by the biofloc biomass that is formed which can contribute to nutrients or additional food for fish in the culture pond (Widanarni et al., 2008). The formation of biofloc with a probiotic starter from the swamp bacteria (Bacillus sp. and Streptomyces sp.) has been known to improve the nutritional content of the feed (Widanarni et al., 2012) and help digestion and increase fish growth (Antika, 2019; Wijayanti et al., 2020).

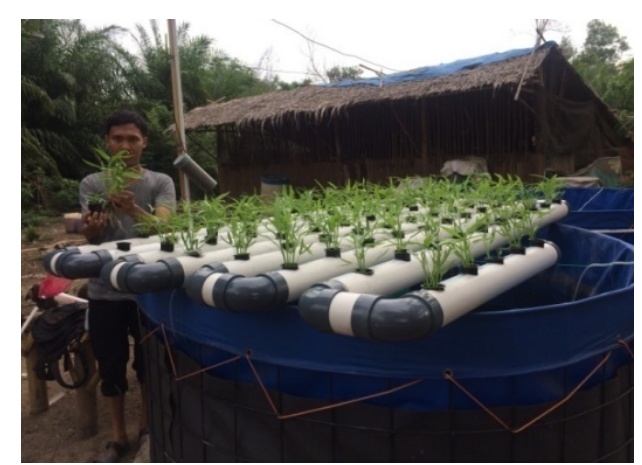

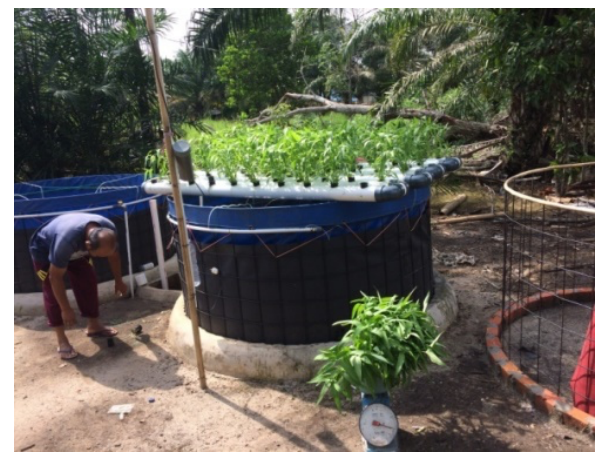

Figure 5. The Biofoc and Biofloqua circular pond.

Table 1 shows the weight gain and total length of water spinach, respectively $18.21 \pm 3.50$ grams and $29.86 \pm 2.12 \mathrm{~cm}$ with total biomass obtained between 5.5$6 \mathrm{~kg}$ at harvest after 20 days. According to Sayekti et al. (2018), cultivating water spinach or vegetable on the media-rich organic matter will increase the growth of water spinach plants. The media-rich organic matter can be from the fish cultivation waste or organic fertilizer. The advantages of combined biofloc and aquaponics technology can reduce high ammonia in the aquaculture media by vegetables and the microbes on the root. The recirculation and absorption of nutrients can improve the water quality of aquaculture media (Setijaningsih, 2009). 

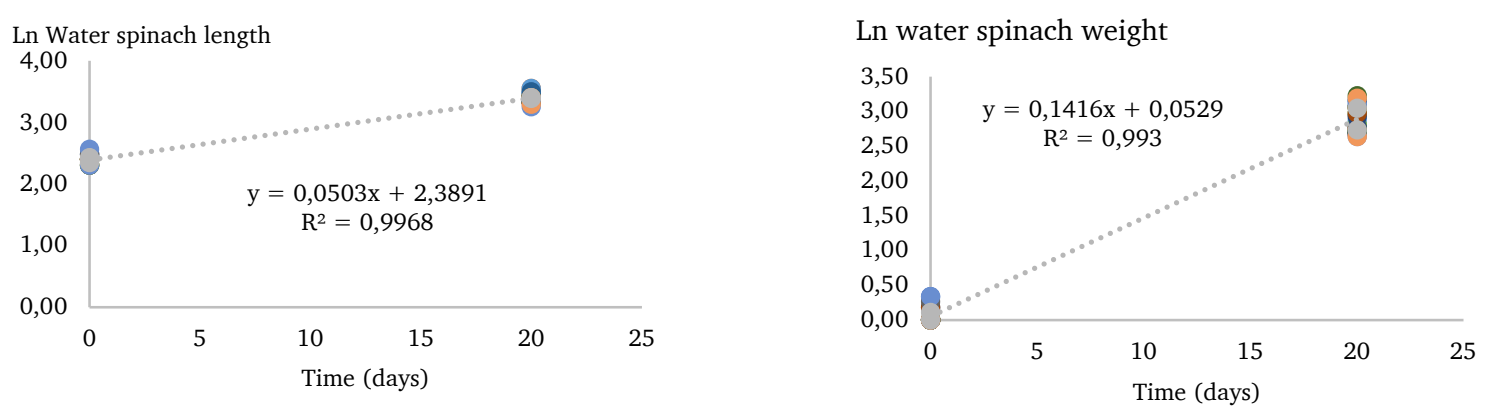

Figure 6. Regression graph of the total length and weight of water sinach in the Biofloqua system.

The specific growth rates for length and weight of water spinach were $5.03 \%$ and $14.16 \%$ per day, respectively (Figure 6). Catfish pond waste is rich in organic matter and the role of microbes will help decompose ammonia into nitrates so that the growth of water spinach is optimal (Pitrianingsih et al., 2014). The availability of organic cultivation waste and water recirculation greatly affects plant growth. The vegetable plant can effectively utilize the nutrients (elements of carbon and nitrogen) for its growth. It can reduce the ammonia value to 0.22 mg. $1^{-1}$ in 3 weeks of rearing (Perdana et al., 2015). To optimize the growth of pond vegetable plants, it is advisable to stock the seeds for at least 1 week after raising the fish. It takes control of the flow of water to the plant roots to keep the supply of oxygen and water for optimizing the role of the microbial root. Water spinach plants can generally be harvested 4 -5 times for 3 months of rearing fish. They can be harvested starting from the planting age of 18 days (25-28 days from seedlings in rock wool) (Rahmadhani et al., 2020).

\section{Water Quality and Catfish Survival Rate}

Data on the results of water quality measurements in biofloc and bioflocaquaponics ponds in rearing time are presented in Table 3. The survival of catfish in the combined biofloc and aquaponic ponds received $96 \%$ which was higher than the $92 \%$ biofloc pond in the first month, but $100 \%$ of both in the second month.

Table 3. Temperature, Dissolved Oxygen, $\mathrm{pH}$ value and Survival Rate of Clarias catfish in rearing time (2 months).

\begin{tabular}{lllll}
\hline \multirow{2}{*}{ Parameter } & \multicolumn{2}{c}{ Biofloc } & \multicolumn{2}{c}{ Biofloqua } \\
& First Month & Second Month & First Month & Second Month \\
\hline Temperature ${ }^{\circ} \mathrm{C}$ & $30,3-31,5$ & $30,7-31,9$ & $29,5-31,0$ & $30,3-31,3$ \\
pH value & $6,5-7,0$ & $6,0-7,0$ & $6,5-7,0$ & $6,0-7,0$ \\
Dissolved Oxygen $\left(m g .1^{-1}\right)$ & $4,5-7,1$ & $5,4-7,2$ & $4,7-7,4$ & $5,8-7,3$ \\
Ammonia (mg.1 $\left.1^{-1}\right)$ & - & - & 0,71 & 0,53 \\
Survival Rate (\%) & 92 & 96 & 100 & 100 \\
\hline
\end{tabular}

In the first month, the condition of the biofloc system fish rearing was still unstable. It is showed that the fish survival rate less than $100 \%$. They must be adapted to the system that was formed in both circular pond systems. In the second month, the fish condition was more stable.
Both the biofloc and biofloqua systems were able to maintain their survival rate up to $100 \%$. The high survival in biofloc circulation media that was integrated with the aquaponic recirculation system can be caused by the existence of a water quality maintenance system from plants. They 
utilize organic matter from fish excretion to become nutrients with the help of microbes attached to plant roots and floc form in culture media. The water circulation through plants provides benefits for fish, because ammonia, nitrite, and nitrate waste can be utilized by plants for their growth. The plants reduced waste contamination, so the water quality can be optimized for fish rearing (Kurniawan et al., 2018).

The causes of catfish mortality during maintenance can be influenced by changes in temperature during the dry season which causes stress for fish due to hot weather and rain usually affects outdoor ponds with water levels below one meter (Boyd,1989). The change in water temperature of the rearing media always follows the change of weather. Stress on fish causes fish to be susceptible to disease. If it lasts for a long time, it will reduce appetite until the fishes die. Decreasing $\mathrm{pH}$ and dissolved oxygen can cause decreasing in probiotic's decomposing organic matter. It could be the accumulation of feces into ammonia. The fish can be poisoned with ammonia $\left(\mathrm{NH}_{3}\right)$. Measurement of ammonia during maintenance after a change of water in the second week of rearing. The ammonia concentration value of the biofloc pond was $0.27 \mathrm{mg} . \mathrm{l}^{-1}$ and the biofloc aquaponics pond was $0.20 \mathrm{mg} \cdot \mathrm{l}^{-1}$. Both ammonia values were still classified as safe for catfish farming activities $<0.8 \mathrm{mg} . \mathrm{l}^{-1}$ (BBPBAT, 2005).

The water quality data presented in the table above shows the temperature range of the biofloc pond from 30.3$31.9^{\circ} \mathrm{C}$ and $29.5-31.3^{\circ} \mathrm{C}$ in the combined pool of biofloc with aquaponics. Both ponds had a decrease in temperature as a result of the change in seasons from dry to rainy season. The temperature in the combined biofloc and aquaponics ponds is lower due to the construction of plant containers above the rearing ponds. The temperature obtained in maintenance is classified as a standard temperature for catfish cultivation of $22-32^{\circ} \mathrm{C}$ (BBPBAT, 2005). Dissolved oxygen concentrations consistently showed that the combined consistently showed that the combined pool of biofloc and aquaponics was higher with a range of 4.7-7.4 mg. $\mathrm{l}^{-1}$ in the first month; 5.8-7.34 mg..$^{-1}$ in the second month and the biofloc pool 4.5-7.2 mg..$^{-1}$ in the first month; 5.4-7.2 mg.1-1 in the second month, according to the dissolved oxygen requirement of catfish. Boyd (1997) stated that catfish can get the body with dissolved oxygen levels of $3 \mathrm{mg} \cdot \mathrm{l}^{-1}$. The $\mathrm{pH}$ value of the two ponds ranged from 6.0 to 7.0 , indicating a decrease in $\mathrm{pH}$, presumably due to the accumulation of organic matter and the effect of rainfall. Overall water quality in the cultivation of the biofloc system and the combination of biofloc and aquaponics shows that there is an improvement in water quality and an increase in fish survival in the presence of floc-forming probiotics (Bacillus sp. and Streptomyces sp.) which can maintain water quality and at the same time prevent pathogenic infections. (Citra, 2019; Wijayanti et al., 2020).

The regression analysis of fish survival in the two systems tested, both Biofloc and Biofloqua. It showed high survival in the Biofloqua system (Figure 7). The $100 \%$ survival for two months of rearing shows the stable performance of the fish being reared. The regression results of the relationship between fish survival and rearing time (days), namely $\mathrm{y}=-2.81 \ln (\mathrm{x})+100.21(\mathrm{RZ}=0.9796)$. It means that for the maintenance of catfish until harvest for 3 months (90 days), the survival rate can be maintained around $87.57 \%$ of the number of fish at the beginning of stocking Based on the survival regression equation in the biofloc system, the $85 \%$ viability of survival can still be supported by this Biofloc system with a maintenance time of 7.5 months (224.3 days).

\section{Volume of Floc and Growth of water spinach}

The data of floc volume in rearing time of catfish are presented at Figure 7. 


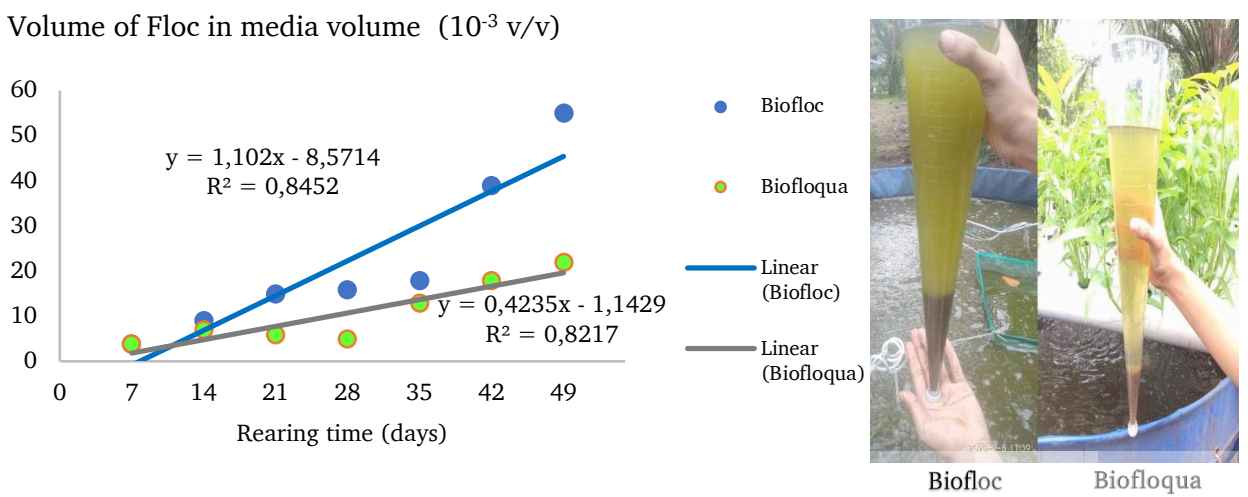

Figure 7. Floc volume in Biofloc and Biofloqua system ponds for rearing time 49 days.

Figure 7 shows the measurement results of the volume of floc formed at the end of maintenance, for a $55 \mathrm{ml}^{-1}{ }^{-1}$ nonbiofloqua pond, which was higher than the combined biofloc and aquaponics pond, which was only $22 \mathrm{ml} \cdot 1^{-1}$. The floc volume formation rate in the biofloc system alone reached $1.1 \mathrm{ml}^{-1}{ }^{-1}$ per day, which was above the floc formation rate for the 0.42 ml. $1^{-1}$ biofloc system per day. This can be caused by the presence of aquaponic plants that utilize biofloc-forming nutrients, both carbon and nitrogen sources, which are used as nutrients for plant growth. The decrease in floc volume occurs due to increased utilization of waste by plants at the end of rearing time. Floc volume is influenced by organic matter and recirculation through plants which filter fish feces and reduce the organic matter in the water. The floc formed in biofloqua pond is lower due to the absorption of organic matter for plant growth (Sayekti et al., 2018).

Although the biofloqua fish growth was not significantly higher than the biofloc fish growth, the Biofloqua system (aquaponics of water spinach which was integrated with biofloc system) became a new system that could be an alternative to increase the income of fish farmer by harvesting vegetables and fish.

\section{CONCLUSION}

The combination of biofloc and aquaponics (Biofloqua system) showed better growth and survival performance of catfish. Both Biofloc and Biofloqua systems were efficient in feed FCR less than 1.00. Water spinach can grow by utilizing aquaculture waste, although it reduces floc volume, it can be an additional product in catfish production.

\section{ACKNOWLEDGMENT}

Gratitude to the University of Sriwijaya, which has funded the Community Service program in 20192020 in the scheme of innovation, and to all those who helped to complete the study of rural communities Sakatiga especially Mr. Sunarso, SP and farmer groups, and their agribusiness Raudhatul Ulum boarding school residents.

\section{REFERENCES}

Alfia, R.A., Arini, dan Elfitasari, T., 2013. Alfia, A.R., Arini, E. and Elfitasari, T., 2013. Pengaruh kepadatan yang berbeda terhadap kelulushidupan dan pertumbuhan ikan nila (Oreochromis niloticus) pada sistem resirkulasi dengan filter bioball. Journal of Aquaculture Management and Technology, 2(3), pp.86-93. https://ejournal3.undip.ac.id/index .php/jamt/article/view/4796

Andrews, L., Higgins, A., Andrews, M.W. and Lalor, J.G., 2012. Classic Grounded Theory to Analyse Secondary Data: Reality and Reflections. The Grounded Theory Review, 11(1), pp.12-26. http://gro undedtheoryreview.com/wp-conten t/uploads/2014/03/110 1_01.pdf

Antika, R.M., 2019. Kepadatan Bakteri, Efisiensi Pakan, dan Pertumbuhan 
Bakteri Kandidat Probiotik Asal Rawa. Skripsi. Fakultas Pertanian Universitas Sriwijaya.

Balai Besar Pengembangan Budidaya Air Tawar (BBPBAT), 2005. Petunjuk Pembenihan Ikan Lele Sangkuriang (Clarias sp.). Sukabumi.

Boyd, C.E., 1989. Water Quality Management and Aeration in Shrimp Farming. Fisheries and Allied Aquacultures Departement Series No.2. Alabama Agramiculture Experiment Station. Auburn University. Alabama.

Boyd, C.E., 1997. Practical aspects of chemistry in pond aquaculture. The Progressive Fish-Culturist, 59(2), pp.85-93. https://doi.org/10.1577/ 1548-8640(1997)059\%3C0085:PA OCIP\%3E2.3.CO;2

Citra, N., 2019. Pengaruh Pemberian Bakteri Asal Rawa Kandidat Probiotik Dalam Pakan Untuk Mencegah Infeksi Bakteri Aeromonas Hydrophila pada Ikan Gabus (Channa Striata). Skripsi. Fakultas Pertanian Universitas Sriwijaya.

Crab, R., Avnimelech, Y., Defoirdt, T., Bossier, P. and Verstraete, W., 2007. Nitrogen removal techniques in aquaculture for a sustainable production. Aquaculture, 270(1-4), pp.1-14. https://doi.org/10.1016/j. aquaculture.2007.05.006

Crab, R., Defoirdt, T., Bossier, P. and Verstraete, W., 2012. Biofloc technology in Aquaculture Beneficial Effects and Future Challenges. Aquaculture. 356-357, pp.351-356. https://doi.org/10.10 16/j.aquaculture.2012.04.046

da Rocha, A.F., Biazzetti Filho, M.L., Stech, M.R. and da Silva, R.P., 2017. Lettuce Production In Aquaponic And Biofloc Sistems With Silver Catfish Rhamdia quelen. Boletim do Instituto de Pesca, 43(Especial), pp.64-73. DOI: 10.20950/16782305.2017.64.73

De Schryver, P., Crab, R., Defoirdt, T., Boon, N. and Verstraete, W., 2008.
The basics of bio-flocs technology: the added value for aquaculture. Aquaculture, 27(3-4), pp.125-137. https://doi.org/10.1016/j.aquacult ure.2008.02.019

Direktorat Jenderal Perikanan Budidaya (DJPB), 2018. Kementrian Kelautan dan Perikanan Selenggarakan Bimbingan Teknis Bantuan Pemerintah Budidaya Ikan Lele Sistem Bioflok [online]. (accessed 20 September 2019)

Effendie, M.I., 2002. Biologi Perikanan (Edisi Revisi). Penerbit Yayasan Pustaka Nusantara Yogyakarta, p.163.

Ekasari, J., 2009. Bioflocs Technology: Theory and Application in Intensive Aquaculture System. Jumal Akuakultur Indonesia. 8(2), pp.117126. https://doi.org/10.19027/jai.8 .117-126

Faridah, F., Diana, S. and Yuniati, Y., 2019. Budidaya Ikan Lele Dengan Metode Bioflok Pada Peternak Ikan Lele Konvesional. CARADDE: Jurnal Pengabdian Kepada Masyarakat, 1(2), pp.224-227. https://doi.org/1 0.31960/caradde.v1i2.74

Goada, A.M.A., Essa, M.A., Hassaan, M.S. and Sharawy, Z., 2015. Bio Economic Features for Aquaponic Systems in Egypt. Turkish Journal of Fisheries and Aquatic Sciences, 15(3), pp.525-532. DOI: 10.4194/13032712-v15 240

Handajani, H., 2011. Optimalisasi Substitusi Tepung Azolla Terfermentasi pada Pakan Ikan Untuk Meningkatkan Produktivitas Ikan Nila Gift. Jurnal Teknik Industri, 12(2), pp.177-181. https://doi.org/10.22219/JTIUMM. Vol12. No2.177-181

Hanley, ., 1991. Effects of feeding supplementary diets containing varying levels of lipid on growth, food conversion, and body composition of Nile tilapia, Oreochromis niloticus (L.). Aquaculture, 93(4), pp.323-334. 
https://doi.org/10.1016/0044-848

6(9 1)90224-U

Kurniawan, A., Asriani, E. and Sari, S.P., 2018. Bioflok dan Akuaponik untuk Bangka Belitung. Malang: Media Nusa Kreatif.

Perdana, T.R., Raza'i, T.S. and Zulfikar, A., 2015. Tingkat Penyerapan Tanaman Kangkung (Ipomoea reptans) Dengan Luasan Wadah Tanam Sistem Akuaponik Yang Berbeda Terhadap Kandungan Amonia (NH3) Pada Limbah Budidaya Lele. Manajemen Sumberdaya Perairan, FIKP UMRAH, p.9.

Pinho, S.M., Molinari, D., de Mello, G.L., Fitzsimmons, K.M. and Emerenciano, M.G.C., 2017. Effluent from a biofloc technology (BFT) tilapia culture on the aquaponics production of different lettuce varieties. Ecological Engineering, 103(A), pp.146-153. https://doi.org/10.1016/j.ecoleng. 2017.03.009

Pitrianingsih, C., Suminto and Sarjito, 2014. Pengaruh bakteri kandidat probiotik terhadap perubahan kandungan nutrien $\mathrm{C}, \mathrm{N}, \mathrm{P}$ dan $\mathrm{K}$ media kultur lele dumbo (Clarias gariepinus). Journal of Aquaculture Management And Technology, 3(4), pp.247-256. https://ejournal3.undi p.ac.id/index.php/jamt/article/vie $\mathrm{w} / 7340$

Pratama, W.D., Prayogo and Manan, A., 2017. Pengaruh Pemberian Probiotik Berbeda dalam Sistem Akuaponik terhadap Kualitas Air pada Budidaya Ikan Lele (Clarias sp.). Journal of Aquaculture. 1(1), pp.27-35. https://doi.org/10.3109 3/joas.v1i1.4

Puspita, E.V. and Sari, R.P., 2018. Effect of different stocking density to growth rate of catfish (Clarias gariepinus, burch) cultured in biofloc and Nitrobacter media. Aquasains Jurnal Ilmu Perikanan dan Sumberdaya Perairan, 6(2), pp.563-568. http://d x.doi.org/10.23960/aqs.v6i2.p583588
Rahmadhani, L.E., Widuri, L.I. and Dewanti, P., 2020. Kualitas Mutu Sayur Kasepak (Kangkung, Selada, Dan Pakcoy) Dengan Sistem Budidaya Akuaponik Dan Hidroponik. Jurnal Agroteknologi, 14(1), pp.33-43. https://doi.org/10 .19184/j-agt.v14i01.15481

Rimbiyastuti, H., Suwarsono and Julianto, A.Y., 2016. Pengaruh Konsentrasi Larutan Garam Beryodium $(\mathrm{NaCl})$ Terhadap Daya Hambat Bakteri Streptococcus mutans. Jurnal Kesehatan Gigi, 3(1), pp.30-33. https://doi.org/10.31983/jkg.v3i01 .1125

Rusliadi, R., Putra, I., Fauzi, M., Pamukas, N.A. and Masjudi, H., 2018. Pengembangan mata pencaharian alternatif bagi nelayan melalui kegiatan budidaya ikan dengan teknologi bioflok di Kampung Sungai Kayu Ara. Riau Journal of Empowerment, 1(2), pp.61-65. https ://doi.org/10.31258/raje.1.2. 8

Shah, M.R., Lutzu, G.A., Alam, A., Sarker, P., Chowdhury, M.K., Parsaeimehr, A., Liang, Y. and Daroch, M., 2018. Microalgae in aquafeeds for a sustainable aquaculture industry. Journal of Applied Phycology, 30(1), pp.197-213. https://doi.org/10.100 7/s10811-017-1234-z

Sayekti, R.S., Prajitno, D. and Indradewa, D., 2018. Pengaruh Takaran Pupuk Kandang dan Kompos terhadap Pertumbuhan Daun Kangkung (Ipomea Reptans) Akuaponik. Agrotechnology Innovation (Agrinova), 1(1), pp.15-22. https:// doi.org/10.22146/agrinova.41776

Setijaningsih, L., 2009. Peningkatan Produktivitas Kolam Melalui Perbedaan Jarak Tanam Tanaman Akuaponik pada Pemeliharaan Ikan Mas (Cyprinus carpio). Laporan Hasil Riset Perikanan Budidaya Air Tawar Bogor

Simanjuntak, I.C.B.H., 2017. Perbedaan Konsentrasi Bakteri Penyusun Bioflok terhadap Efisiensi Pemanfaatan Pakan, Pertumbuhan, 
dan Kelulushidupan Ikan Lele Dumbo (Clarias gariepinus). Jurnal Sains Teknologi Akuakultur. 1(1), pp.47-55. http://jsta.aquasiana.org /index.php/jmai/article/view/7

Sucipto, A., Sunarma, A., Yanti, D.H., Maskur and Rahmat, 2018. Perbaikan Sistem Budidaya Ikan Nila Melalui Teknologi Bioflok. Jurnal Perekayasaan Akuakultur Indonesia 1(2), pp.115-128. https://kkp.go.id/an-component/m edia/upload-gambar-pendukung/D JPB/Pustaka/Jurnal\%20Perksain\% 20Vol\%202\%20No\%201\%20Juni\% 202018.pdf

Suryaningrum, F,M., 2014. Aplikasi Teknologi Bioflok Pada Pemeliharaan Benih Ikan Nila (Oreochromis niloticus). Thesis. Universitas Terbuka, p.110.

Widanarni, W., Sukenda, S. and Setiawati, M., 2008. Bakteri probiotik dalam budidaya udang: seleksi, mekanisme aksi, karakterisasi, dan aplikasinya sebagai agen biokontrol. Jurnal Ilmu Pertanian Indonesia, 13(2), pp.8089. https://journal.ipb.ac.id/index. php/JIPI/article/view/6594

Widanarni, W., Wahjuningrum, D. and Puspita, F., 2012. Aplikasi Bakteri Probiotik melalui Pakan Buatan untuk Meningkatkan Kinerja Pertumbuhan Udang Windu (Penaeus monodon). Jurnal Sains Terapan, 2(1), pp.19-29. https://doi .org/10.29244/jstsv.2.1.19-29

Wijayanti, M., Jubaedah, D., Yulistya, O., Tanbiyaskur and Sasanti, A.D., 2020. Optimization of striped snakehead fish (Channa striata) culture using swamp microbial combination and nitrification bacteria. AACL Bioflux, 13(2), pp.1064-1078. http://www.bioflux. com.ro/docs/2020.1064-1078.pdf 